Relations industrielles

Industrial Relations

\title{
Wei Chiao Huang (Ed.), Organized Labor at the Crossroads
}

\section{Jonathan Reshef}

Volume 46, numéro 1, 1991

URI : https://id.erudit.org/iderudit/050658ar

DOI : https://doi.org/10.7202/050658ar

Aller au sommaire du numéro

Éditeur(s)

Département des relations industrielles de l'Université Laval

ISSN

0034-379X (imprimé)

1703-8138 (numérique)

Découvrir la revue

Citer ce compte rendu

Reshef, J. (1991). Compte rendu de [Wei Chiao Huang (Ed.), Organized Labor at the Crossroads]. Relations industrielles / Industrial Relations, 46(1), 234-236.

https://doi.org/10.7202/050658ar

Tous droits réservés @ Département des relations industrielles de l'Université Laval, 1991
Ce document est protégé par la loi sur le droit d'auteur. L'utilisation des services d'Érudit (y compris la reproduction) est assujettie à sa politique d'utilisation que vous pouvez consulter en ligne.

https://apropos.erudit.org/fr/usagers/politique-dutilisation/ 
En effet, les trois derniers chapitres du livre sont liés et s'inscrivent dans le courant de l'école française de la régulation. L'auteur ne cache pas ses sympathies personnelles pour ces développements théoriques et cela se sent dans le traitement même de la matière. La présentation est plus fouillée et plus complète, oubliant parfois qu'elle s'adresse à des débutants. Cette partie conviendrait mieux à un cours plus avancé. L'auteure y traite de la théorie de la régulation, après avoir passé rapidement par Marx, enchaîne avec la théorie du dualisme et de la segmentation du marché du travail pour terminer finalement avec la présentation du fonctionnement des marchés internes du travail. Ces trois derniers chapitres mettent clairement en évidence le rôle des institutions sur le marché du travail, choix qui nous apparaît très approprié.

Ginette DUSSAULT

Université Laval

Organized Labor at the Crossroads, edited by Wei-Chiao Huang, Kalamazoo, Michigan, E.E. Upjohn Institute for Employment Research, 1989, 162 p., ISBN 0-88099-075-9.

The six papers in this book were presented during the 24th annual Lecture-Seminar Series conducted by the Department of Economics at Western Michigan University during the academic year 1987-1988. The book is unified by the introductory chapter written by WeiChiao Huang. Among the questions the six scholars deal with are: Why are unions declining? How are unions responding to the changing world? And, what is the future of American labor unions?

In chapter 2 , Sharon $P$. Smith presents a case study of collective bargaining between the American Telephone and Telegraph Company (AT\&T) and the representing unions, primarily the Communications Workers of America (CWA), from 1984 to 1986. This highly informative chapter demonstrates that adjusting to a changing, much more competitive, environment can be a slow and painful process for both management and worker representatives. Smith's major conclusion is that success in this area is best achieved through a collaborative approach, when all the parties involved share in the responsibility of the decision and the rewards that result. While this conclusion has been repeated in a great number of recent industrial relations studies, it remains unclear just how to convince those parties who have long adopted an adversarial approach to industrial relations to radically change their practices and phylosophies and adopt a more cooperative approach.

In chapter 3, Kochan and Cutcher-Gershenfeld ask whether the 1980s' innovations and experiments in labor-management relations will diffuse to a broader array of bargaining relationships and become institutionalized as regular aspects of labor-management relations. To answer this question they analyze four industrial relations innovations - employee participation, flexible forms of work organization, employee participation in technological changes, and union participation in strategic management decisions - in nine companies.

Regarding employee participation, they claim that on their own QWL programs are too narrow to be able to sufficiently contribute to a high-trust employee-management relationship. It requires commitment of top management and union leaders to expand the scope of participation into a wider variety of issues involving work organization, technological change and business strategy.

Regarding work organization reforms, they found that it is easier to introduce flexible work rules and practices in new workplaces than to retrofit an existing facility with new systems. 
Turning to technological innovations, they stress that to integrate technology and industrial relations requires fundamental and lasting changes in the roles of union leaders, workers and managers, and in their relationships. Such integration will facilitate the introduction of new technology as it defuses worker and union resistance to new technology.

To implement the last innovation - union participation in strategic management decisions - both parties must introduce a radical and lasting change in their established, adversarial relationship. The conditions necessary for this innovation will be met through "bottomup" incremental expansions of participation rather than through direct and formal board representation by the union.

To sum, the theme that underlies this chapter is that if recently introduced workplace innovations are to become a new industrial relations order, the adversarial union-management relationship must make way for a new, more cooperative employee/ union-employer relationship. Whether the parties are capable of such a radical and lasting change in their established industrial relations philosophies and practices is yet to be seen.

In chapter 4, George E. Johnson reviews labor's political agenda with respect to policy toward the labor market and collective bargaining, international trade policy, and women in the labor market. Two major themes appear in his discussion. First, many of the AFL-CIO's political positions arise from self-interest as well as from a sincere wish to help the less privileged. An example of the former position is the federation's unconditional support for the Davis-Bacon Act (which requires any construction project which is financed by federal funds to pay wages similar to what other construction workers in the area are paid). An example of the latter position is the AFL-CIO's strong support for progressive tax increases which will hurt many union members.

A second, most interesting theme in Johnson's discussion is labor's ideological shift from voluntarism to a greater government intervention in the economy at a micro level. The old adage of "reward our friends and punish our enemies" may be losing favor with American unions as the number of their friends is diminishing at an alarming pace. Disenchanted with the "invisible hand of the market", unions are turning to the government to help them stop their dramatic decline. A shift that has been anathema to most "pure and simple" American unions' phylosophies over the last nine decades.

In chapter 5, Martin L. Weitzman argues about the advantage of implementing profit sharing programs to reconcile reasonably full employment with reasonable price stability. "When part of a worker's pay is a share of profits, the company has an automatic inducement to take on more employees in good times and, what is probably more significant, to lay off fewer workers during bad times" (p. 96). Yet, it is not all that clear, at least to this reader, why in a share economy employers would retain employees after contractionary shocks.

From an industrial relations viewpoint, his basic argument is that in a wage economy worker alienation is commonplace as the employer is indifferent to whether the worker stays or goes. Weitzman believes that in a share economy the wage vs. job conflict that pits younger, untenured workers against older high-seniority workers will be eliminated, workers will be more receptive to technological changes, and workers will be more committed to the well-being of their employing organization.

In chapter 6, Richard Freeman presents an ambitious attempt to account for the changing status of unionism around the world. Two themes emerge from his discussion. First, it is the institutions that govern industrial relations, foremost among them is labor legislation, rather than macro-level economic forces that shape unions' growth and decline patterns. These 
institutions impact management's role in determining union status. And, it is management attitude and practice toward trade unions which is the single most important factor in patterns of unionism.

I find this argument overly deterministic. It is, for example, impossible to use it to explain the dramatic decline of French unions under the Mitterrand administration (1981 to present). During Mitterrand's tenure unions have enjoyed unprecedented pro-labor legislation, and management which has been anything but aggressively anti union. I also find his analysis lacking any serious attempt to relate current union status to unions' historical development. I believe that any comparative analysis of the current status of unions must start with a deep historical analysis, as it is not always clear which is the cause and which is the effect when one deals with unionization and any other related variables such as legislation.

Second, speculating on the future of trade unions in eastern Europe, Freeman believes that "unions or related worker organizations will achieve increasing independence and play a major role in reforming Communist economies" (p. 125). Among the reasons he gives are that unions provide workers with a "voice" option. Workers, wishing to protest poor working conditions, can use unions to improve working conditions. This way workers should not resort to reducing work effort, the only option of protest available to disgruntled workers under traditional "command economies". Additionally, Freeman claims that unions can play a major role in a successful transition to market economy. Successful perestroika needs independent unions who are major agents of opposition to those bureaucrats who try to undermine perestroika.

In the last chapter, Orley Ashenfelter deals with the interest arbitration system for settling wage disputes in the U.S. public sector. His analysis seriously questions the common view that conventional arbitration, in which the arbitrators commonly "split the differences" between the parties' last offers, tends to produce a "chilling effect," whereas final-offer arbitration avoids this effect because the parties try to narrow down their differences for the fear that the arbitrator might select a more reasonable offer made by the other party.

According to his analysis, arbitrators behave consistently regardless of the type of the arbitration system. Whether the arbitrator operates a conventional or final-offer arbitration system, he/she would use external criteria to reach a reasonable award. Thus, the uncertainty associated with any arbitration process motivates the parties to negotiate their own settlement in order to avoid the uncertainty involved in the arbitration process, which is why neither system produces chilling effects.

This collection, while including interesting papers on a variety timely topics, suffers from a lack of internal consistency. It is not clear, for example, why the last paper on interest arbitration is included in a book the theme of which is organized labor at a crossroads. The collection lacks a synthesizing final chapter that would relate all of the major ideas to each other. Still, this book offers some innovative ideas on the state of U.S. unions and industrial relations and students of these topics may find it useful.

Yonathan RESHEF 